\title{
$\alpha, \beta$-Aziridinylphosphonates by lithium amide-induced phosphonyl migration from nitrogen to carbon in terminal aziridines
}

\author{
David. M. Hodgson ${ }^{*}$ and Zhaoqing Xu
} Open Access

\author{
Full Research Paper \\ Address: \\ Department of Chemistry, Chemistry Research Laboratory, University \\ of Oxford, Mansfield Road, Oxford, OX1 3TA, UK, Fax: +44(1865) \\ 285002 \\ Email: \\ David. M. Hodgson* - david.hodgson@chem.ox.ac.uk \\ * Corresponding author \\ Keywords: \\ amino acids; aziridines; lithiation; migration; synthetic methods
}

\author{
Beilstein J. Org. Chem. 2010, 6, 978-983. \\ doi:10.3762/bjoc. 6.110 \\ Received: 13 August 2010 \\ Accepted: 28 September 2010 \\ Published: 13 October 2010 \\ Associate Editor: J. Aubé \\ (c) 2010 Hodgson and Xu; licensee Beilstein-Institut. \\ License and terms: see end of document.
}

\begin{abstract}
$N$-Phosphonate terminal aziridines undergo lithium 2,2,6,6-tetramethylpiperidide-induced $N$ - to $C$-[1,2]-anionic phosphonyl group migration under experimentally straightforward conditions, to provide a stereocontrolled access to synthetically valuable trans- $\alpha, \beta-$ aziridinylphosphonates. The utility of this chemistry has been demonstrated in the asymmetric synthesis of a $\beta$-aminophosphonate.
\end{abstract}

\section{Introduction}

The synthesis of aminophosphonic acids and their derivatives has attracted considerable attention, since the presence of such functionality, typically as amino acid surrogates, leads to interesting bioactivity in, for example, antibacterial agents, enzyme inhibitors and herbicides [1-3]. $\alpha, \beta$-Aziridinylphosphonates $\mathbf{3}$, while possessing biological activity themselves, can be converted into aminophosphonic acids using various ringopening processes [4-6]. Aziridinylphosphonates 3 have previously been prepared by a variety of methods [4-6], of which ring-closure following either Sharpless aminohydroxylation of $\alpha, \beta$-unsaturated phosphonates [7], or $\alpha$-halophosphonate addition to sulfinimines [8] constitute notable asymmetric approaches, albeit principally leading to $\beta$-aryl substituted $\alpha, \beta$ aziridinylphosphonates. Arising from our investigations [9-13] on the generation and subsequent chemistry of $\alpha$-lithiated terminal aziridines [14], we considered whether $\alpha, \beta$ aziridinylphosphonates 3 could be accessed by $\alpha$-lithiation of $N$-phosphonate terminal aziridines $\mathbf{1}$, followed by $N$ - to $C$-[1,2]anionic phosphonyl group migration in lithiated intermediate $\mathbf{2}$ (Scheme 1). Here, we present full details of this study [15].

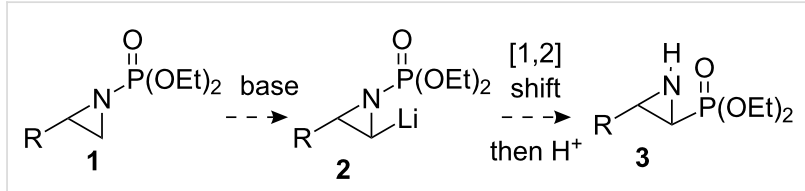

Scheme 1: Proposed aziridinyl anion induced $N$ - to $C$-phosphonyl migration. 
Based-induced migration, involving cleavage of a nitrogen phosphorus bond and formation of a carbon phosphorus bond, was first reported over 30 years ago by Hellwinkel and co-workers $(\mathbf{4} \rightarrow \mathbf{5}$, Scheme 2$)$ [16,17]. More recently, Modro et al. reported a similar ortho-lithiation followed by [1,3]-shift of a phosphonyl group $(\mathbf{6} \rightarrow 7$, Scheme 2) [18]; related processes have been observed with diazaphospholidine oxides [19] and bicyclic phosphoric triamides [20]. Benzylic lithiation-induced $N$ - to $C$-[1,2]-anionic phosphonyl rearrangements $(\mathbf{8} \rightarrow \mathbf{9}$, Scheme 2) were developed by Hammerschmidt and Hanbauer [21], and a stereoretentive $N$ - to $C$-[1,2]-shift in an $\alpha$-lithiated pyrrole involving a chiral tert-butyl(phenyl)phosphinyl group has been reported [22].<smiles>Cc1ccc(N(C)P(=O)(c2ccccc2)c2ccccc2)c(Br)c1</smiles>

4<smiles>CCOP(=O)(OCC)c1ccccc1NC</smiles><smiles>[R]N(C[Al])P(=O)(OCC)OCC[As]</smiles>

$\left(\mathrm{R}=\mathrm{Boc}, \mathrm{PO}(\mathrm{OEt})_{2}, \mathrm{CO}_{2} \mathrm{Li}\right)$

Scheme 2: Selected previously observed $N$ - to $C$-phosphorous migrations $[17,18,21]$.

With regard to previous anion-induced $N$ - to $C$-1,2-shifts in aziridines, in one isolated example, the $N$-Boc-aziridine of styrene was treated with $s$-BuLi in THF at $-98{ }^{\circ} \mathrm{C}$ to give a phenyl-stabilised $\alpha$-lithiated aziridine, which underwent migration to give 2-phenyl-2-Boc-aziridine (90\%) [23]. Also, our laboratory has reported the LTMP (lithium 2,2,6,6-tetramethylpiperidide)-induced rearrangement of a range of terminal $N$-Boc-aziridines to give trans-aziridinyl esters [12,15] (cf. Scheme 1, with $\mathrm{CO}_{2} t-\mathrm{Bu}$ instead of $\left.\mathrm{PO}(\mathrm{OEt})_{2}\right)$. However, prior to our studies only one example of a $N$ - to $C$-[1,2]-anionic rearrangement of an aziridine involving phosphorus had been observed: lithiation-deuteration of $N$-diphenylphosphinylaziridine 10 gave the anticipated deuterated aziridine 11 (70\%), along with the rearranged aziridine 12 (25\%) [24] (Scheme 3).

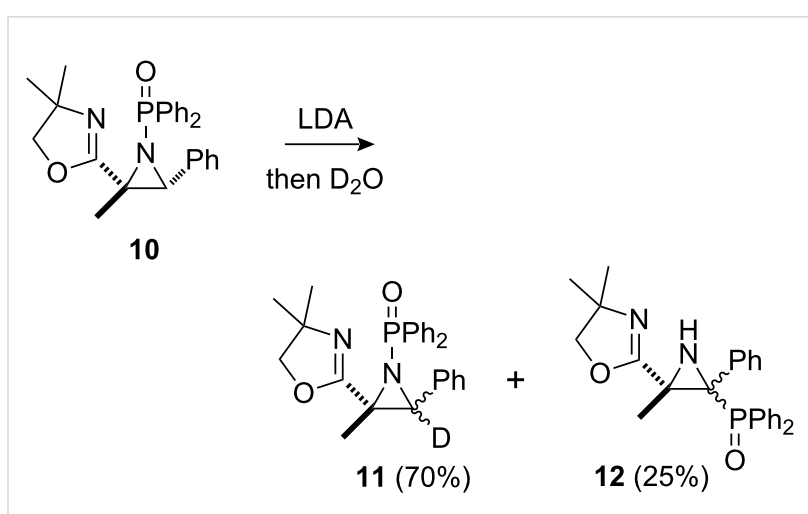

Scheme 3: Partial $N$ - to $C$-migration with $N$-diphenylphosphinylaziridine 10 [24].

\section{Results and Discussion}

So as to examine the migration chemistry outlined in Scheme 1, access to $N$-phosphonate terminal aziridines 1 was required [25]. These can be concisely prepared from alkenes using chemistry developed by Zwierzak and co-workers [26-28]. In a oneflask operation, addition of 1-hexene (13) to $\mathrm{Br}_{2} \mathrm{NPO}(\mathrm{OEt})_{2}$ [29] in the presence of UV light [27] and subsequent treatment with $\mathrm{NaH}$ (2 equiv) [26] gave the representative substrate 1a (57\%, Scheme 4) [28].

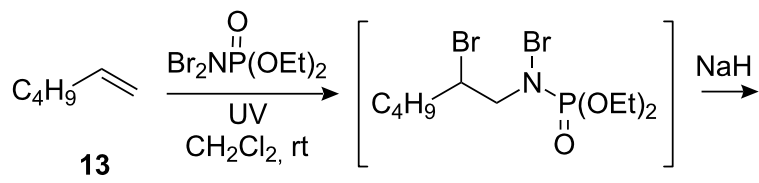

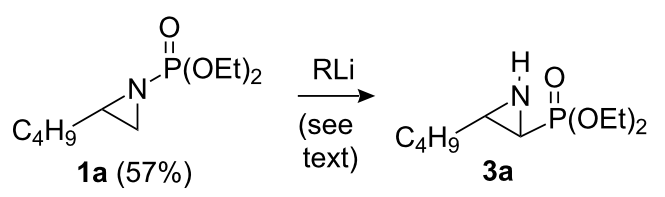

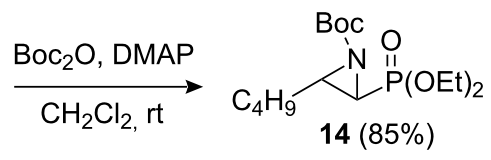

Scheme 4: Synthesis and rearrangement of aziridine 1a.

Initially, we examined organolithiums for their propensity to induce deprotonation-migration in $N$-phosphonate aziridine $\mathbf{1 a}$. Despite it being previously noted by Zwierzak that the reaction of organolithium reagents with such substrates resulted in preferential attack at phosphorus giving a complex mixture of products [30], we did obtain some of the desired rearrangement product 3a (Scheme 4). When aziridine 1a in THF was treated 
with $n$-BuLi (1.5 equiv) at $-78{ }^{\circ} \mathrm{C}$ for $4 \mathrm{~h}, 46 \%$ of rearrangement product 3a was obtained (66\% based on recovered 1a). The stereochemistry of aziridinylphosphonate $\mathbf{3 a}$ was assigned as trans on the basis of the small sizes of the vicinal $\mathrm{H}-\mathrm{H}$ couplings across the ring in 3a and in the derived $N$-Boc aziridinylphosphonate $\mathbf{1 4}(3-3.5 \mathrm{~Hz})$, which are diagnostic for such systems (the corresponding cis-aziridinylphosphonates are known to have larger ${ }^{3} J$ values of $6-7 \mathrm{~Hz}$ ) $[31,32]$. Generation of trans-stereochemistry was also observed in the corresponding $N$-Boc system $[12,15]$ (see earlier discussion), and the present transformation likely follows a similar reaction pathway: initial trans $\alpha$-lithiation, which is probably assisted by prior complexation of the base with the $\mathrm{N}$-protecting group, followed by intramolecular migration [12] of this group.

Reactions of $s$-BuLi or $t$-BuLi with aziridine 1a under the same conditions as above were less effective, giving a $22 \%$ yield of 3a $(50 \%$ based on recovered $\mathbf{1 a})$ and only traces of $\mathbf{3 a}(45 \% \mathbf{1 a}$ recovered), respectively. In an attempt to induce greater conversion of $1 \mathrm{a}$ with $n$-BuLi, the amount of the latter was increased to 3 equivalents, however only $25 \%$ of $\mathbf{3 a}$ was obtained. Given previous successes with the use of lithium amides to deprotonate differently $N$-protected terminal aziridines [9-14], we moved on to study such bases with $N$-phosphonate aziridine 1a. Firstly, LDA (lithium diisopropylamid) and $\mathrm{LiNCy}_{2}$ were examined. Although there was no significant increase in yield on using LDA or $\mathrm{LiNCy}_{2},(38 \%$ and $15 \%$ of $\mathbf{3 a}$, respectively), under the same conditions as for $n$-BuLi described above, side-reactions were not observed. These results prompted us to try the stronger lithium amide, LTMP. Initial studies indicated that with 3 equiv of LTMP, 3a was obtained in 52\% yield (94\% based on recovered 1a). Prolonging the reaction time from 4 to $8 \mathrm{~h}$ made no difference to the yield. However, when the amount of LTMP was increased to 4 equiv and to 5 equiv, 3 a was obtained in $65 \%$ and $91 \%$ yields, respectively. These latter conditions were then applied to a range of terminal $N$-phosphonate aziridines 1 (Table 1).

Terminal aziridine $\mathbf{1 b}$, possessing secondary alkyl substitution on the aziridine, gave the rearranged aziridinylphosphonate $\mathbf{3 b}$ in $79 \%$ yield (Table 1, entry 2). Aziridines 1c and 1d underwent migration smoothly without complications arising from potential allylic deprotonation [33], intramolecular cyclopropanation [11,12] or benzylic deprotonation (entries 3 and 4). Mixed results were obtained when the method was applied to substrates possessing silyl ether functionality. The distalprotected aziridine 1e provided stable aziridinylphosphonate $\mathbf{3 e}$ in high yield (entry 5), whereas rapid decomposition was observed during attempted purification of the product mixture from the proximal-protected substrate $\mathbf{1 h}$ (Figure 1). However, the migration reaction could be used to prepare aziridinylphos- phonate 3f (entry 6), without potential elimination [34] of the primary chloride. From 2-chloroethylamine hydrochloride, the simplest $N$-phosphonate aziridine 1i (Figure 1) could be straightforwardly accessed [35]. However, this latter substrate decomposed under the lithiation conditions. A 2,2-disubstituted $\mathrm{N}$-phosphonate aziridine 1g, available from isobutene and $\mathrm{Br}_{2} \mathrm{NPO}(\mathrm{OEt})_{2}$ without UV assistance followed by methanolic $\mathrm{NaOMe}$-induced ring-closure $[26,27,30]$, proved viable in the lithiation [1,2]-shift chemistry giving aziridinylphosphonate $\mathbf{3 g}$ (58\%, Table 1 , entry 7). However, and similarly to the $N$-Boc aziridine of cyclohexene $[12,15]$, no reaction was observed between LTMP and a 2,3-disubstituted aziridine 1j (Figure 1), presumably due to steric interactions and/or reduced acidity impeding lithiation.

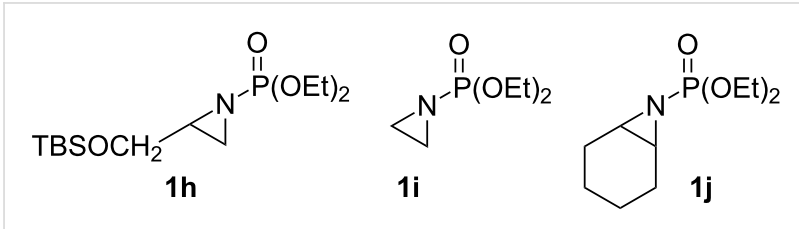

Figure 1: Aziridines 1h-j.

LDA has been reported to rapidly (THF, $-78{ }^{\circ} \mathrm{C}, 10 \mathrm{~min}$ ) isomerize $N$-Ph cis- $\beta$-phenyl-aziridinylphosphonate to mainly (80:20) the trans-isomer 3 ( $\mathrm{NPh}$ instead of $\mathrm{NH}$, and $\mathrm{R}=\mathrm{Ph}$ ) via an $\alpha$-deprotonation pathway [36]. Therefore, although substrate and/or product co-ordination and/or LTMP aggregation phenomena could be invoked to rationalise the beneficial effect of the excess LTMP on yield, and we viewed $\alpha$-deprotonation as more difficult in our likely post-rearrangement intermediate $\mathbf{3}$ (N-Li instead of $\mathrm{N}-\mathrm{H}$, Scheme 1), we sought to rule out the possibility that LTMP might be being consumed by further lithiation in the rearranged product. In the event, quenching a migration reaction of $N$-phosphonate aziridine 1a with $\mathrm{CD}_{3} \mathrm{OD}$ did not show any deuterium incorporation. This prompted a closer investigation of the reaction using a more rigorously purified sample of aziridine 1a than which had been used in our preliminary studies. This latter work established that direct application of our earlier $N$-Boc migration conditions (3 equiv LTMP, $-78^{\circ} \mathrm{C}, 90 \mathrm{~min}$ ) [12] gave complete consumption of the starting aziridine 1a, with aziridinylphosphonate $\mathbf{3 a}$ being isolated in $82 \%$ yield (use of 2 equiv LTMP gave 3a in $68 \%$ yield, with 7\% recovered 1a) and suggests that 5 equiv of the base may not always be needed to effect efficient rearrangement.

Asymmetric access to an aziridinylphosphonate was also explored to demonstrate further the utility of the above methodology. As terminal epoxides are readily available as single enantiomers [37], terminal epoxide-opening with $\mathrm{H}_{2} \mathrm{NPO}(\mathrm{OEt})_{2}$ 


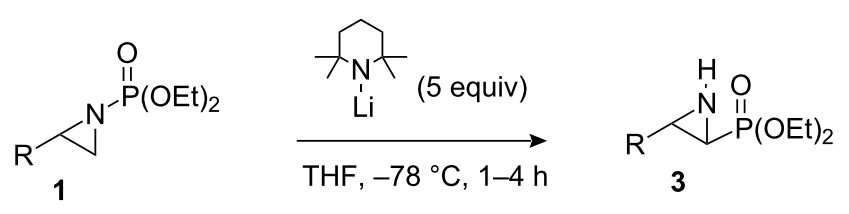

\begin{tabular}{lll}
\hline Entry & Aziridine 1 Aziridinylphosphonate 3 \\
\hline
\end{tabular}

1<smiles>CCO[N+]1(C=O)CC1[13CH3]</smiles>

1 a

2<smiles>[CH]C1CN1[P+](O)(OCC)OCC</smiles>

$1 \mathrm{~b}$

3<smiles>C=CCCC1CN1P(=O)=O</smiles>

4<smiles>CCO[P+](=O)N1CC1CCc1ccccc1</smiles>

$1 d$<smiles>CCCCCCCCC1CN1[Pb](=O)OCC</smiles>

6<smiles>CCO[P+](=O)N1CC1[14CH2]Cl</smiles>

7<smiles>CCO[P+](=O)N1CC1(C)C</smiles>

$1 \mathrm{~g}$<smiles>CCOC(=O)N1C([13CH3])C1(O)OCC</smiles>

91

$3 a$<smiles>[CH]C1NC1P(=O)(OCC)OCC</smiles>

79

3b<smiles>C=CCCC1NC1P(=O)(OCC)OCC</smiles>

79

87<smiles>CCO[PH2+](=O)C1NC1CCc1ccccc1</smiles>

3d<smiles>CCOP(=O)(OCC)C1C(N)C1CCCOS(=O)(=O)O</smiles>

95

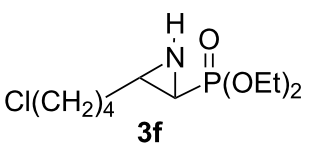

87<smiles>CCO[PH](=O)C1NC1(C)C</smiles>

58

$3 g$

followed by ring-closure was initially considered as a potential asymmetric route to $N$-phosphonate terminal aziridines $\mathbf{1}$. However, 1,2-epoxyhexane could not be successfully ringopened with $\mathrm{H}_{2} \mathrm{NPO}(\mathrm{OEt})_{2}$ under a variety of conditions $(\mathrm{NaH}$, $\mathrm{KH}$, or $\mathrm{NaH} / \mathrm{DMPU}$ in THF; $(i \text {-PrO })_{4} \mathrm{Ti}$ or $\mathrm{BF}_{3} \cdot \mathrm{Et}_{2} \mathrm{O}$ in $\mathrm{CH}_{2} \mathrm{Cl}_{2}$; aminolytic kinetic resolution [12,38]), and use of $\left(\mathrm{Me}_{3}\right) \mathrm{SiHNPO}(\mathrm{OEt})_{2}$ [39] also proved ineffective. A convenient asymmetric access was eventually developed, starting with ring-opening of commercially available $(R)$-1,2-epoxybutane
(15) using ammonia, which gave $\beta$-amino alcohol 16 in good yield (Scheme 5) [40]. By analogy with a preparation of $\mathrm{N}$-diphenylphosphinyl aziridines [41], subsequent one-pot $\mathrm{N}$ and $O$-phosphonylation followed by $\mathrm{NaH}$-induced ring-closure gave $(S)$-aziridine $1 \mathbf{k}(52 \%)$. Lithiation-rearrangement of $(S)$ aziridine $\mathbf{1 k}$ provided aziridinylphosphonate (-)-3k in excellent yield $(89 \%)$, and without any degradation of enantiopurity ( $>99 \%$ ee, as determined by chiral HPLC analysis of the benzoyl derivative 17). 


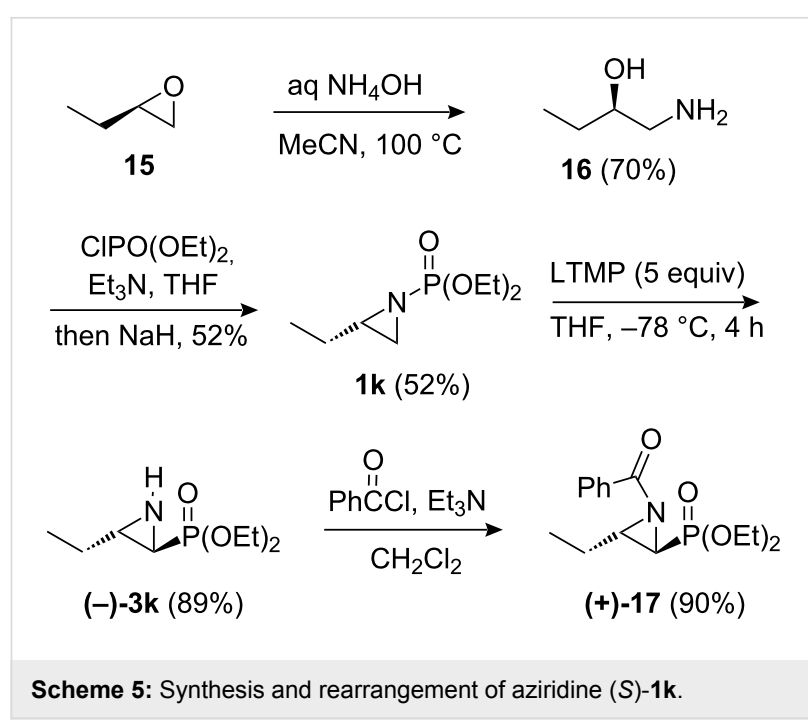

Hydrogenolytic ring-opening of aziridinylphosphonates provides an attractive entry to $\alpha$ - or $\beta$-aminophosphonates [6] $\alpha, \beta$-Aziridinylphosphonates bearing a $\beta$-aryl group undergo cleavage at the formally benzylic $\mathrm{C}-\mathrm{N}$ bond, leading to $\alpha$-aminophosphonates. With $\beta$-alkyl groups, regioselectivity is influenced by the presence or absence of an $N$-substituent. $N$-Ts Cis- $\beta$-alkyl-substituted aziridinylphosphonates give $\beta$-aminophosphonates [32], whereas both $N$-Boc cis- and trans$\beta$-alkyl-substituted aziridinylphosphonates lead to $\alpha$-aminophosphonates. For example, hydrogenolysis of $N$-Boc trans-aziridinylphosphonate 14 ( $\mathrm{Bn}$ instead of the $\mathrm{C}_{4} \mathrm{H}_{9}$ group) using $10 \% \mathrm{Pd} / \mathrm{C}\left(\mathrm{H}_{2}(1 \mathrm{~atm}), \mathrm{EtOH}, 12 \mathrm{~h}\right)$ has been reported to give the corresponding $N$-Boc $\alpha$-aminophosphonate (63\%) [31] In the absence of an $N$-substituent, $c i s-\beta$-alkyl-substituted aziridinylphosphonates give $\beta$-aminophosphonates [32] and we observed that trans- $\beta$-alkyl-substituted aziridinylphosphonate (-)-3k underwent completely regioselective hydrogenolysis under transfer hydrogenation conditions [31] to produce $\beta$-aminophosphonate $(+)-\mathbf{1 8}[32,42]$ in $68 \%$ yield with $>99 \%$ ee (determined by chiral HPLC analysis of the benzoyl derivative 19, Scheme 6).

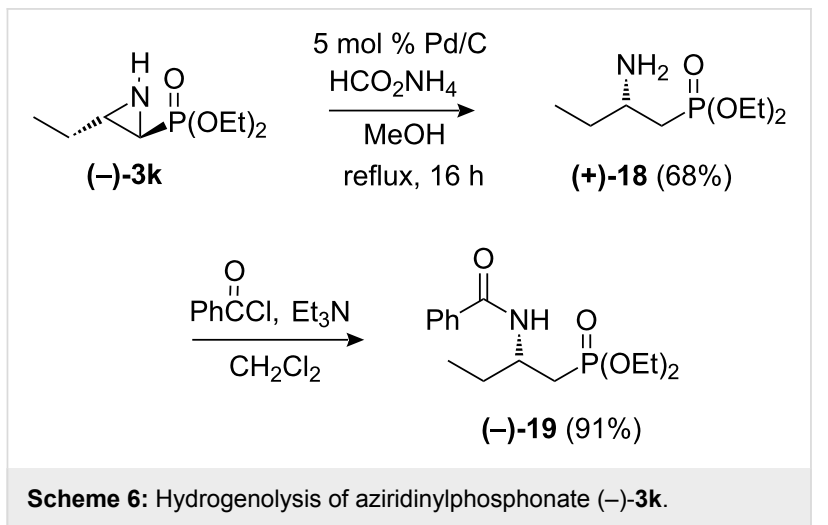

\section{Conclusion}

In summary, lithiation-induced phosphonyl migration from nitrogen to carbon in terminal aziridines 1 effects simultaneous $\mathrm{N}$-deprotection and accesses synthetically valuble $\mathrm{N}-\mathrm{H}$ transaziridinylphosphonates $\mathbf{3}$. The process is experimentally straightforward to carry out and occurs in an efficient and completely stereocontrolled fashion. The utility of the chemistry is further highlighted by a subsequent conversion into an enantiopure $\beta$-aminophosphonate 18, demonstrating an entry to a biologically important $\beta$-amino acid mimic class.

\section{Supporting Information}

Full preparative details of all compounds are reported, together with their spectroscopic data.

\section{Supporting Information File 1}

Experimental and analytical data

[http://www.beilstein-journals.org/bjoc/content/ supplementary/1860-5397-6-110-S1.pdf]

\section{Acknowledgements}

We thank the Royal Society for an International Incoming Fellowship (to Z. X.), P. G. Humphreys for some additional experimental results, C. Pousset (Solvay) for hydrogenolysis details and the EPSRC National Mass Spectrometry Service Centre for mass spectra.

\section{References}

1. Kukhar, V. P.; Hudson, H. P., Eds. Aminophosphonic and Aminophosphinic Acids: Chemistry and Biological Activity; Wiley: Chichester, 2000.

2. Palacios, F.; Alonso, C.; de los Santos, J. M. Chem. Rev. 2005, 105, 899-932. doi:10.1021/cr040672y

3. Orsini, F.; Sello, G.; Sisti, M. Curr. Med. Chem. 2010, 17, 264-289. doi:10.2174/092986710790149729

4. Moonen, K.; Laureyn, I.; Stevens, C. V. Chem. Rev. 2004, 104, 6177-6216. doi:10.1021/cr030451c

5. Zhou, P.; Chen, B.-C.; Davis, F. A. Asymmetric Syntheses with Aziridinecarboxylate and Aziridinephosphonate Building Blocks. In Aziridines and Epoxides in Organic Synthesis; Yudin, A. K., Ed.; Wiley-VCH: Weinheim, 2006; pp 73-115. doi:10.1002/3527607862.ch3

6. Singh, G. S.; D'hooghe, M.; De Kimpe, N. Chem. Rev. 2007, 107, 2080-2135. doi:10.1021/cr0680033

7. Thomas, A. A.; Sharpless, K. B. J. Org. Chem. 1999, 64, 8379-8385. doi:10.1021/jo990060r

8. Davis, F. A.; Wu, Y.; Yan, H.; McCoull, W.; Prasad, K. R. J. Org. Chem. 2003, 68, 2410-2419. doi:10.1021/jo020707z

9. Hodgson, D. M.; Humphreys, P. G.; Ward, J. G. Org. Lett. 2005, 7, 1153-1156. doi:10.1021/ol050060f

10. Hodgson, D. M.; Miles, S. M. Angew. Chem., Int. Ed. 2006, 45, 935-938. doi:10.1002/anie.200503303 
11. Hodgson, D. M.; Humphreys, P. G.; Ward, J. G. Org. Lett. 2006, 8 , 995-998. doi:10.1021/ol060101n

12. Hodgson, D. M.; Humphreys, P. G.; Miles, S. M.; Brierley, C. A. J.; Ward, J. G. J. Org. Chem. 2007, 72, 10009-10021. doi:10.1021/jo701901t

13. Hodgson, D. M.; Humphreys, P. G.; Hughes, S. P. Pure Appl. Chem. 2007, 79, 269-279. doi:10.1351/pac200779020269

14. Florio, S.; Luisi, R. Chem. Rev. 2010, 110, 5128-5157. doi:10.1021/cr100032b

15. Hodgson, D. M.; Humphreys, P. G.; Xu, Z.; Ward, J. G. Angew. Chem., Int. Ed. 2007, 46, 2245-2248. doi:10.1002/anie.200604920

16. Hellwinkel, D.; Hofmann, G.; Lämmerzahl, F. Tetrahedron Lett. 1977, 18, 3241-3244. doi:10.1016/S0040-4039(01)83207-X

17. Hellwinkel, D.; Lämmerzahl, F.; Hofmann, G. Chem. Ber. 1983, 116, 3375-3405. doi:10.1002/cber.19831161014

18. Jardine, A. M.; Vather, S. M.; Modro, T. A. J. Org. Chem. 1988, 53, 3983-3985. doi:10.1021/jo00252a019

19. Legrand, O.; Brunel, J. M.; Buono, G. Angew. Chem., Int. Ed. 1999, 38, 1479-1483. doi:10.1002/(SICI)1521-3773(19990517)38:10<1479::AID-ANIE1479>3 .0.CO;2-G

20. He, Z.; Modro, T. A. Synthesis 2000, 565-570. doi:10.1055/s-2000-6368

21. Hammerschmidt, F.; Hanbauer, M. J. Org. Chem. 2000, 65, 6121-6131. doi:10.1021/jo000585f

22. Au-Yeung, T.-L.; Chan, K.-Y.; Haynes, R. K.; Williams, I. D.; Yeung, L. L. Tetrahedron Lett. 2001, 42, 457-460. doi:10.1016/S0040-4039(00)01952-3

23. Capriati, V.; Florio, S.; Luisi, R.; Musio, B. Org. Lett. 2005, 7, 3749-3752. doi:10.1021/ol051412I

24. Luisi, R.; Capriati, V.; Florio, S.; Di Cunto, P.; Musio, B. Tetrahedron 2005, 61, 3251-3260. doi:10.1016/j.tet.2005.01.045

25. Sweeney, J. B. Aziridines. In Science of Synthesis: Houben-Weyl Methods of Molecular Transformations; Enders, D., Ed.; Thieme: Stuttgart, 2008; Vol. 40a, pp 643-772.

26. Zwierzak, A.; Zawadzki, S. Synthesis 1972, 416-417. doi:10.1055/s-1972-21890

27. Zawadzki, S.; Zwierzak, A. Tetrahedron 1981, 37, 2675-2681. doi:10.1016/S0040-4020(01)98974-4

28. Osowska-Pacewicka, K.; Zwierzak, A. J. Prakt. Chem. 1986, 328, 441-444. doi:10.1002/prac.19863280321

29. Zawadzki, S.; Zwierzak, A. Tetrahedron 1973, 29, 315-320. doi:10.1016/S0040-4020(01)93296-X

30. Gajda, T.; Napieraj, A.; Osowska-Pacewicka, K.; Zawadzki, S.; Zwierzak, A. Tetrahedron 1997, 53, 4935-4946. doi:10.1016/S0040-4020(97)00188-9

31. Pousset, C.; Larchevêque, M. Tetrahedron Lett. 2002, 43, 5257-5260. doi:10.1016/S0040-4039(02)01035-3

32. Palacios, F.; Aparicio, D.; Ochoa de Retana, A. M.; de los Santos, J. M.; Gil, J. I.; López de Munain, R. Tetrahedron: Asymmetry 2003, 14, 689-700. doi:10.1016/S0957-4166(03)00089-2

33. Mordini, A.; Peruzzi, D.; Russo, F.; Valacchi, M.; Reginato, G.; Brandi, A. Tetrahedron 2005, 61, 3349-3360. doi:10.1016/j.tet.2005.01.102

34. Hodgson, D. M.; Bray, C. D.; Kindon, N. D.; Reynolds, N. J.; Coote, S. J.; Um, J. M.; Houk, K. N. J. Org. Chem. 2009, 74, 1019-1028. doi:10.1021/jo802016t
35. Osowska-Pacewicka, K.; Zwierzak, A. Synthesis 1996, 333-335. doi:10.1055/s-1996-4213

36. Coutrot, P.; Elgadi, A.; Grison, C. Heterocycles 1989, 28, 1179-1192. doi:10.3987/COM-88-S147

37. Schaus, S. E.; Brandes, B. D.; Larrow, J. F.; Tokunaga, M.; Hansen, K. B.; Gould, A. E.; Furrow, M. E.; Jacobsen, E. N. J. Am. Chem. Soc. 2002, 124, 1307-1315. doi:10.1021/ja016737।

38. Bartoli, G.; Bosco, M.; Carlone, A.; Locatelli, M.; Melchiorre, P.; Sambri, L. Org. Lett. 2004, 6, 3973-3975. doi:10.1021/ol048322I

39. Zwierzak, A. Synthesis 1982, 920-922. doi:10.1055/s-1982-29996

40. Wenghoefer, H. M.; Lee, K. T.; Srivastava, R. M.; Srimannarayana, G.; Clapp, L. B. J. Heterocycl. Chem. 1970, 7, 1407-1411. doi:10.1002/jhet.5570070631

41. Osborn, H. M. I.; Cantrill, A. A.; Sweeney, J. B.; Howson, W. Tetrahedron Lett. 1994, 35, 3159-3162. doi:10.1016/S0040-4039(00)76856-0

42. Yuan, C.; Xu, C.; Zhang, Y. Tetrahedron 2003, 59, 6095-6102. doi:10.1016/S0040-4020(03)00995-5

\section{License and Terms}

This is an Open Access article under the terms of the Creative Commons Attribution License (http://creativecommons.org/licenses/by/2.0), which permits unrestricted use, distribution, and reproduction in any medium, provided the original work is properly cited.

The license is subject to the Beilstein Journal of Organic Chemistry terms and conditions:

(http://www.beilstein-journals.org/bjoc)

The definitive version of this article is the electronic one which can be found at: doi:10.3762/bjoc. 6.110 